\title{
Effects of Apremilast on Binge Drinking and Circadian Gene Expression in High Drinking in the Dark Mice
}

Courtney Ledford

Portland State University

Follow this and additional works at: https://pdxscholar.library.pdx.edu/mcnair Let us know how access to this document benefits you.

\section{Recommended Citation}

Ledford, Courtney (2021) "Effects of Apremilast on Binge Drinking and Circadian Gene Expression in High Drinking in the Dark Mice," PSU McNair Scholars Online Journal: Vol. 15: Iss. 1, Article 5.

https://doi.org/10.15760/mcnair.2021.15.1.5 
I. Introduction.

Alcohol use disorder (AUD) negatively impacts individuals, communities and has a significant economic effect. Binge drinking is the third leading cause of preventable deaths in the United States (Sacks et al., 2015; Witkiewitz et al., 2019). Binge drinking is characterized as reaching a blood alcohol level $(\mathrm{BAL})$ of $>80 \mathrm{mg} \%$ within a 2-hour time period (National Institute on Alcohol Abuse and Alcoholism, 2004). The COVID-19 pandemic has brought further challenges to those with AUD, as a change in alcohol availability and the impact of isolation have caused an increase in alcohol use. In contrast, countries that enacted alcohol restrictions have shown higher rates of fatal alcohol withdrawal (Nadkarni et al., 2020).

Alcoholism causes a disruption in circadian rhythms that continues into sobriety and increases the risk for relapse (Brower, 2001; Fonzi et al., 1994; Landolt et al., 1996; Sano et al., 1993). Circadian rhythms operate on a 24-hour time period to regulate the sleep/wake cycle, hormone regulation, physiology, and behavior. The cyclical rhythm has known peaks and troughs that fluctuate and are affected by light input. The ventral tegmental area (VTA) plays an important role in reward, motivation, addiction, and molecular clock function. The Ozburn lab found abstinence from ethanol causes a reduced expression of the Circadian Locomotor Output Cycles Kaput (Clock) gene in the VTA of wild-type (WT) mice (Ozburn et al., 2013).

To study the effects of apremilast on binge-like drinking, high drinking in the dark (HDID) mice are used as a model organism. The HDID mice were bred to binge drink and show withdrawal following a single drinking session. These mice were chosen as they are genetically identical, allowing for a high-risk model for binge-like ethanol drinking (Crabbe et al., 2017, 2009). 
Harm reduction research is necessary to alleviate the effects of chronic binge drinking. Improving circadian rhythms, which are affected during and following drinking, may lessen the harmful effects of alcohol. Individuals with disturbed circadian rhythms are more apt to relapse. Remediating the effects of binge drinking on the circadian rhythm suggests the potential to decrease alcohol intake while increasing Clock function. In addition, pharmacologically targeting the phosphodiesterase-4 (PDE4) inhibitor may increase Clock gene expression in the VTA and decrease alcohol intake.

\section{Research Question.}

The research question addresses if PDE4 inhibitor, apremilast, can reduce binge-like drinking in HDID mice. Furthermore, the experiment investigates if apremilast increases levels of circadian gene expression in the VTA of HDID mice with a history of chronic binge-like drinking. The expected results of apremilast treatment will increase Clock gene expression in the VTA and decrease binge-like drinking.

\section{Literature Review.}

Ethanol consumption affects Clock gene expression in animal models, as shown by the Ozburn lab. Research suggests mice with a mutation in the Clock gene (Clock $\Delta 19)$ have an increased preference for stimulant rewards and sucrose. Reducing Clock function in the VTA of WT mice increased the amount of ethanol consumed, similar to the Clock $\Delta 19$ mice. The Ozburn lab found Clock expression in the VTA plays an important role as a negative regulator of ethanol intake (Ozburn et al., 2013).

Another medication that has been researched to rescue the harmful effects of chronic binge drinking is rolipram. Rolipram and apremilast are shown to increase cyclic adenosine monophosphate (cAMP); both these medications are PDE4 inhibitors. PDE4 is an enzyme 
responsible for the hydrolysis of cAMP. Compounds that increase cAMP can increase circadian gene expression (Clarke et al., 2017; Spanagel et al., 2005a, Spanagel et al., 2005b). Rolipram was shown to reduce ethanol intake in mice (Hu et al., 2011). Apremilast is FDA approved for psoriasis and psoriatic arthritis, and in preclinical trials is shown to reduce ethanal intake (Blednov et al., 2018).

IV. Methodology.

This experiment uses adult male and female inbred HDID as a simple chronic binge-like drinking genetic animal model. This experiment uses an 8-week Drinking in the Dark (DID) paradigm. Two-time points were accessed to account for the circadian peaks and troughs of nocturnal drinking patterns. Mice were given access to ethanol $20 \%$ at 3 hours into their active dark cycle [Zeitgeber time (ZT 15)]. At ZT 15 the mice are active with the lights turned off. Timepoint ZT 3 is a trough in gene expression where circadian genes are least expressed. Whereas $Z T 15$, is a peak in expression and circadian genes show a higher rate of expression while the mice are active.

For the DID, the mice were given access to water or ethanol $20 \%$ at the timepoint $Z T 15$. The first days of DID, days 1-3, lasted 2 hours, while the final DID session on day 4 lasted 4 hours. The mice underwent DID for 6 weeks to develop a high binge-like drinking average baseline. For weeks 7 and 8, the mice received intraperitoneal injections (IP) of saline or $40 \mathrm{mg} / \mathrm{kg}$ apremilast an hour prior to DID. Euthanization of mice was performed one day after the final DID session at either $Z T 3$ or $Z T 15$ to account for the peaks and troughs.

Circadian gene expression is measured using qualitative real-time polymerase chain reaction (qPCR). The VTA mRNA is isolated and quantified using a method described by (Ozburn et al., 2017). The levels of Clock expression is measured by synthesis of cDNA using the BioRad iScript 
Kit. The levels of circadian genes (Clock, Npas, Perl, or Per 2) will be measured in comparison to 18 s, a housekeeping gene that remains unchanged following ethanol exposure or change in time. Data analysis will use a 3-way ANOVA to compare across (sex $\mathrm{x}$ treatment $\mathrm{x} Z$ ZT). If no sex differences are found, the data will be collapsed across sex for analyses and compared across treatment and time tissue was collected.

\section{Discussion.}

This experiment is ongoing, and the results expected from this correlational study include an increase in circadian gene expression in the VTA ameliorating the effects of chronic bingelike drinking on the molecular clock. Treatment is expected to decrease the amount of ethanol voluntarily consumed while normalizing circadian gene expression. This study will examine the mechanism of action for the use of apremilast treatment to understand the effects on binge-like drinking. A limitation of this preliminary study is the absence of a water control group to test the effects of apremilast on fluid intake. This is an important first step in determining the effects of treatment, as early data shows apremilast to be useful in nontreatment-seeking AUD individuals (Walker \& Lawrence, 2018). Regulation of the molecular clock is important as chronic binge drinking disrupts the expression of genes associated with neuronal signaling, cellular metabolism, immune signaling, and hormone regulation. Going forward, this pilot project will determine if more control groups and time points will be studied to better understand the effects of apremilast on circadian rhythm within the VTA and decrease ethanol binge-like drinking. 


\section{References}

Atkinson, S.E., Maywood, E.S., Chesham, J.E., Wozny, C., Colwell, C.S., Hastings, M.H., Williams, S.R., 2011. Cyclic AMP signaling control of action potential firing rate and molecular circadian pacemaking in the suprachiasmatic nucleus. J. Biol. Rhythms. https://doi.org/10.1177/0748730411402810

Blednov, Y.A., Da Costa, A.J., Tarbox, T., Ponomareva, O., Messing, R.O., Harris, R.A., 2018. Apremilast Alters Behavioral Responses to Ethanol in Mice: I. Reduced Consumption and Preference. Alcohol. Clin. Exp. Res. https://doi.org/10.1111/acer.13616

Brower, K. J. (2001). Alcohol's Effects on Sleep in Alcoholics. Alcohol Research \& Health, 25(2), 110-125.

Clarke, T.K., Adams, M.J., Davies, G., Howard, D.M., Hall, L.S., Padmanabhan, S., Murray, A.D., Smith, B.H., Campbell, A., Hayward, C., Porteous, D.J., Deary, I.J., McIntosh, A.M., 2017. Genome-wide association study of alcohol consumption and genetic overlap with other health-related traits in UK biobank (N=112117). Mol. Psychiatry. https://doi.org/10.1038/mp.2017.153

Crabbe, J. C., Metten, P., Rhodes, J. S., Yu, C.-H., Brown, L. L., Phillips, T. J., \& Finn, D. A. (2009). A Line of Mice Selected for High Blood Ethanol Concentrations Shows Drinking in the Dark to Intoxication. Biological Psychiatry, 65(8), 662-670. https://doi.org/10.1016/j.biopsych.2008.11.002

Crabbe, J. C., Ozburn, A. R., Metten, P., Barkley-Levenson, A., Schlumbohm, J. P., Spence, S. E., Hack, W. R., \& Huang, L. C. (2017). High Drinking in the Dark (HDID) mice are sensitive to the effects of some clinically relevant drugs to reduce binge-like drinking. Pharmacology Biochemistry and Behavior, 160, 55-62. https://doi.org/10.1016/j.pbb.2017.08.002

Fonzi S, Solinas GP, Costelli P, et al. Melatonin and cortisol circadian secretion during ethanol withdrawal in chronic alcoholics. Chronobiologia. 1994 Jan-Jun;21(1-2):109-112. PMID: 7924629.

Gamsby, J.J., Templeton, E.L., Bonvini, L.A., Wang, W., Loros, J.J., Dunlap, J.C., Green, A.I., Gulick, D., 2013. The circadian Per1 and Per2 genes influence alcohol intake, reinforcement, and blood alcohol levels. Behav. Brain Res. https://doi.org/10.1016/j.bbr.2013.04.016

Hu, W., Lu, T., Chen, A., Huang, Y., Hansen, R., Chandler, L.J., Zhang, H.T., 2011. Inhibition of phosphodiesterase-4 decreases ethanol intake in mice. Psychopharmacology (Berl). https://doi.org/10.1007/s00213-011-2290-8

Landolt, H.P., Roth, C., Dijk, D.J., Borbély, A.A., 1996. Late-afternoon ethanol intake affects nocturnal sleep and the sleep EEG in middle-aged men. J. Clin. Psychopharmacol. https://doi.org/10.1097/00004714-199612000-00004

Nadkarni, A., Kapoor, A., \& Pathare, S. (2020). COVID-19 and forced alcohol abstinence in India: The dilemmas around ethics and rights. International Journal of Law and Psychiatry, 71, 101579. https://doi.org/10.1016/j.ijlp.2020.101579 
National Institute on Alcohol Abuse and Alcoholism, 2004. NIAAA Council Approves Definition of Binge Drinking. NIAAA Newsl.

Ozburn, A.R., Falcon, E., Mukherjee, S., Gillman, A., Arey, R., Spencer, S., McClung, C.A., (2013). The role of clock in ethanol-related behaviors. Neuropsychopharmacology. https://doi.org/10.1038/npp.2013.138

Ozburn, A.R., Kern, J., Parekh, P.K., Logan, R.W., Liu, Z., Falcon, E., Becker-Krail, D., Purohit, K., Edgar, N.M., Huang, Y., McClung, C.A., 2017. NPAS2 regulation of anxiety-like behavior and GABAA receptors. Front. Mol. Neurosci.

https://doi.org/10.3389/fnmol.2017.00360

Ozburn, A. R., Larson, E. B., Self, D. W., \& McClung, C. A. (2012). Cocaine self-administration behaviors in Clock 19 mice. Psychopharmacology, 223(2), 169-177.

https://doi.org/10.1007/s00213-012-2704-2

Ozburn, A. R., Metten, P., Potretzke, S., Townsley, K. G., Blednov, Y. A., \& Crabbe, J. C. (2020). Effects of Pharmacologically Targeting Neuroimmune Pathways on Alcohol Drinking in Mice Selectively Bred to Drink to Intoxication. Alcoholism: Clinical and Experimental Research, 44(2), 553-566. https://doi.org/10.1111/acer.14269

Parekh, P.K., Ozburn, A.R., McClung, C.A., 2015. Circadian clock genes: Effects on dopamine, reward and addiction. Alcohol. https://doi.org/10.1016/j.alcohol.2014.09.034

Rosenwasser, A.M., Logan, R.W., Fecteau, M.E., 2005. Chronic ethanol intake alters circadian period-responses to brief light pulses in rats. Chronobiol. Int. https://doi.org/10.1081/CBI$\underline{200053496}$

Sacks, J.J., Gonzales, K.R., Bouchery, E.E., Tomedi, L.E., Brewer, R.D., 2015. 2010 National and State Costs of Excessive Alcohol Consumption. Am. J. Prev. Med. https://doi.org/10.1016/j.amepre.2015.05.031

Sano, M., Wendt, P. E., Wirsén, A., Stenberg, G., Risberg, J., \& Ingvar, D. H. (1993). Acute effects of alcohol on regional cerebral blood flow in man. Journal of Studies on Alcohol, 54(3), 369-376. https://doi.org/10.15288/jsa.1993.54.369

Spanagel, R., Pendyala, G., Abarca, C., Zghoul, T., Sanchis-Segura, C., Magnone, M.C., Lascorz, J., Depner, M., Holzberg, D., Soyka, M., Schreiber, S., Matsuda, F., Lathrop, M., Schumann, G., Albrecht, U., 2005a. The clock gene Per2 influences the glutamatergic system and modulates alcohol consumption. Nat. Med. https://doi.org/10.1038/nm1163

Spanagel, R., Rosenwasser, A.M., Schumann, G., Sarkar, D.K., 2005b. Alcohol consumption and the body's biological clock, in: Alcoholism: Clinical and Experimental Research. https://doi.org/10.1097/01.alc.0000175074.70807.fd

Takahashi, J.S., Shimomura, K., Kumar, V., 2008. Searching for genes underlying behavior: Lessons from circadian rhythms. Science (80-. ). https://doi.org/10.1126/science.1158822

Trujillo, J.L., Do, D.T., Grahame, N.J., Roberts, A.J., Gorman, M.R., 2011. Ethanol consumption in mice: Relationships with circadian period and entrainment. Alcohol. https://doi.org/10.1016/j.alcohol.2010.08.016 
Walker, L. C., \& Lawrence, A. J. (2018). Investigational drug therapies in phase I and phase II clinical trials for alcohol use disorders. Expert Opinion on Investigational Drugs, 27(8), 677-690. https://doi.org/10.1080/13543784.2018.1502269

Wang, X., Wang, L., Yu, Q., Xu, Y., Zhang, L., Zhao, X., Cao, X., Li, Y., \& Li, L. (2016). Alterations in the expression of Per1 and Per2 induced by A $\beta 31-35$ in the suprachiasmatic nucleus, hippocampus, and heart of C57BL/6 mouse. Brain Research, 1642, 51-58. https://doi.org/10.1016/j.brainres.2016.03.026

Witkiewitz, K., Litten, R.Z., Leggio, L., 2019. Advances in the science and treatment of alcohol use disorder. Sci. Adv. https://doi.org/10.1126/sciadv.aax4043 